\author{
Bacterial cellulose를 기반으로 하는 투명전도성막의 제조 및 특성평가 \\ 임은채 · 김성준 $* \uparrow \cdot$ 기창두** \\ 전남대학교 바이오에너지 및 바이오소재 협동과정 \\ 500-757 광주광역시 북구 용봉동 300 \\ *전남대학교 환경공학과 \\ 500-757 광주광역시 북구 용봉동 300 \\ **전남대학교 기계공학과 \\ $500-757$ 광주광역시 북구 용봉동 300 \\ (2013년 8월 23일 접수, 2013년 10월 22일 수정본 접수, 2013년 10월 29일 채택)
}

\title{
Fabrication and Characterization of Transparent Conductive Film based on Bacterial Cellulose
}

\author{
Eun-Chae Yim, Seong-Jun Kim*,† and Chang-Doo Kee** \\ Interdisciplinary program of graduate school for bioenergy and biomaterials, Chonnam National University, \\ 300 Youngbong-dong, Buk-gu, Gwangiu 500-757, Korea \\ *Department of Environmental Engineering, Chonnam National University, 300 Youngbong-dong, Buk-gu, Gwangju 500-757, Korea \\ **School of Mechanical Systems Engineering, Chonnam National University, 300 Youngbong-dong, Buk-gu, Gwangju 500-757, Korea \\ (Received 23 August 2013; Received in revised form 22 October 2013; accepted 29 October 2013)
}

\section{요 약}

본 연구에서는 물리적 강도가 뛰어나고 고온에서 안정하며 유연한 친환경 소재인 박테리아 셀룰로오스를 기반으로 투 명 전도성막을 제조하였다. 전기전도성의 확보를 위해 은나노와이어(AgNW)와 그래핀을 도입하였다. 합성한 $\mathrm{AgNW}$ 는 평균적으로 길이 약 $15 \mu \mathrm{m}$, 폭 약 $70 \mathrm{~nm}$ 로 종횡비 214이었다. 종횡비가 클수록 접촉저항을 낮추어 전도성을 개선시키 게 된다. 총 7 가지의 막을 제조하고 열적 및 전기적 물성을 조사하였다. 또 전도성막으로 제조하기 위해서 $\mathrm{BC}$ 막을 칼로 길이 $2 \mathrm{~mm}$, 깊이 $50 \mu \mathrm{m}$ 간격으로 홈을 파서 직교상의 그물모양을 형성한 후 이 홈에 $\mathrm{AgNW}$ 와 그래핀을 채워 넣었다. 대표적으로 $\mathrm{AgNW}$ 첨가막은 두께 $350 \mu \mathrm{m}$, 전자농도 $1.53 \times 10^{19} / \mathrm{cm}^{3}$, 전자이동도 $6.63 \times 10^{5} \mathrm{~cm}^{2} / \mathrm{Vs}$, 비저항 $0.28 \Omega \cdot \mathrm{cm}$ 로 가장 우수한 전기적 특성을 지닌 것으로 평가되었다. 또한 그래핀 첨가막은 두께 $360 \mu \mathrm{m}$, 전자농도 $7.74 \times 10^{17} / \mathrm{cm}^{3}$, 전자 이동도 $0.17 \mathrm{~cm}^{2} / \mathrm{Vs}$, 비저항 $4.78 \Omega \cdot \mathrm{cm}$ 이었다. $550 \mathrm{~nm}$ 광투과는 $\mathrm{AgNW}$ 첨가막 $98.1 \%$, 그래핀 첨가막 $80.9 \%$ 로 투명한 전도성 막이 형성되었다. 모든 막이 평면과 휜 상태에서 LED 점등 실험에서 전구의 밝기에 차이가 있었으나 불이 켜졌 다. $150 \pm 5^{\circ} \mathrm{C}$ 의 열판에서 박테리아 셀룰로오스 막은 형태가 매우 안정하였으나 같은 두께의 PET는 형태가 심하게 변형 되었다. 이러한 연구 결과를 통해 박테리아 셀룰로오스 기반의 투명전도성막을 제조할 수 있는 가능성을 확인하였다.

\begin{abstract}
A transparent film was fabricated based on bacterial cellulose (BC), BC has excellent physical strength and stability at high temperature and it is an environmental friendly flexible material. In order to improve the conductivity, silver nanowire (AgNW) and/or graphene were introduced to the BC membrane. The aspect ratio of the AgNW synthesized in this study was 214 , with a length of $15 \mu \mathrm{m}$ and width of $70 \mathrm{~nm}$. The higher aspect ratio improved the conductivity by reducing the contact resistance. The thermal and electrical properties of 7 types of films prepared were investigated. Each film was fabricated with rectangular shape $(2 \mathrm{~mm} \times 2 \mathrm{~mm} \times 50 \mu \mathrm{m})$. The films were scored with a net shape by a knife, and filled with AgNW and graphene to bestow conductivity. The film filled with AgNW showed favorable electrical characteristics with a thickness of $350 \mu \mathrm{m}$, electron concentration of $1.53 \times 10^{19}$, electron mobility of $6.63 \times 10^{5}$, and resistivity of 0.28 . The film filled with graphene had a thickness of $360 \mu \mathrm{m}$, electron concentration of 7.74 $\times 10^{17}$, electron mobility of 0.17 , and resistivity of 4.78 . The transmittances at $550 \mathrm{~nm}$ were $98.1 \%$ and $80.9 \%$, respectively. All the films were able to light LEDs bulbs although their brightness differed. A thermal stability test of the BC and PET films at $150 \pm 5{ }^{\circ} \mathrm{C}$ showed that the $\mathrm{BC}$ film was more stable, whereas the PET film was quickly banded. From these results, it was confirmed that there it is possible to fabricate new transparent conductivity films based on BC.
\end{abstract}

Key words: Graphene, Silver Nanowire, Bacterial Cellulose, Transparent, Conductivity Film

\footnotetext{
${ }^{\dagger}$ To whom correspondence should be addressed.

E-mail: seongjun@chonnam.ac.kr
} 


\section{1. 서 론}

투명 전도성막은 터치스크린, 태양전지, 광전자기기, 디스플레이 와 같은 곳에 폭넓게 적용할 수 있다[1-3]. 플렉서블 투명 디스플레 이를 구현하기 위해서는 첫 번째로 유연하고 투명한 기판이 요구된다. 현재 주로 사용되고 있는 소재로는 PET[poly(ethylene terephthalate)] 및 실리콘 웨이퍼가 있다. PET의 경우 유리 전이 온도가 $73{ }^{\circ} \mathrm{C}$, 연 화 온도가 $170{ }^{\circ} \mathrm{C}$ 으로 고온에서 열적 안정성이 매우 떨어진다. 또한 실 리콘 웨이퍼의 경우 유연성이 없어서 플렉서블한 디스플레이에 적 용할 수 없는 문제점이 있다. 그러나 박테리아 셀룰로오스 $(\mathrm{BC})$ 는 20 50 nm의 미세섬유가 수소결합에 의해 3차원적 망상구조로 6.6 $\mathrm{GPa}$ 의 높은 인장 탄성율과 $122 \mathrm{MPa}$ 의 높은 인장강도를 가진다. $\mathrm{BC}$ 는 고탄성율, 고결합능, 높은 흡수력, 고보습성, 고결정성 및 생 분해성 등의 뛰어난 물리적 특성을 가지고 있다[4-6]. 친환경적이며 유연하고 물리적 강도가 뛰어난 박테리아 셀룰로오스(BC) 기판을 사용하여 인장강도가 강하고 구부림이 자유로워 다양한 디자인 창 출과 입고 다닐 수 있는 의류용 패선, 의료용 진단 분야까지 확대 적용할 수 있을 것이다. 투명 디스플레이는 건물과 차량의 창문, 상 가의 광고판에 적용 가능하여 정보 제공의 형태로도 활용이 가능할 것이다.

플렉서블 투명 디스플레이를 구현하기 위해서는 두 번째로 투명 한 전도성막이 요구된다. 투명전도막 또는 투명전극재료로 현재 주로 사용되는 것으로 $\mathrm{ITO}[7], \mathrm{ZnO}[8,9]$ 가 있다. 또한 투명전극재료로 $\mathrm{ZTO}[10], \mathrm{TiO}_{2}[11]$ 같은 금속 산화물과 금속 산화물로 구성된 다층 박막이 있다. 그러나 ITO 및 ZTO의 희귀 원소인 In(Indium)의 고 갈에 따른 공급의 한계와 인체 유해성으로 $\mathrm{In}_{2} \mathrm{O}_{3}$ 를 원료로 하는 $\mathrm{ITO}$ 및 $\mathrm{IZO}$ 의 대체 물질 개발이 매우 중요하다. 게다가 금속 산화 물을 유연한 플라스틱 기판에 코팅할 경우 부서지기 쉽고 갈라짐이 심하다. 플렉서블 투명전극으로 대체 물질로는 전도성 폴리머 (PEDOT:PSS), 탄소나노튜브, 그래핀, 금속 나노와이어 등이 있다[2]. 또한 금, 은, 구리 등의 금속을 진공증착법으로 얇은 박막으로 코팅 할 경우 전도성은 우수하지만 투과도 향상을 위해 박막으로 코팅할 경우 금속 필름의 표면 강도가 약해진다. 은을 이용한 은 나노와이 어를 합성하여 적용할 경우에는 은나노와이어가 높은 종횡비 (aspect ratio)로 네트워크를 형성하면서 높은 전도성이 얻어지고 유연한 필 름에 코팅할 경우에 높은 투과율을 확보할 수 있다[12].

그래핀은 강철보다 200 배 강하고 구리보다 100 배 이상 전기가 잘 통하는 기계적 특성 및 전기전도 특성이 우수하고 화학적, 열적 안 정성을 가지며 탄소 원자 하나의 두께 $(0.35 \mathrm{~nm})$ 에 불과하기 때문에 매우 높은 투명도를 지니며 열적/기계적 특성도 우수하다. 또한 전 자 소자의 경우도 가볍고 투명하고 휘어지는 등의 고부가가치 산업 시장으로의 진출에 대한 필요성이 증대되면서 우수한 기계적/광학 적 성질을 가지는 소재에 대한 필요성 또한 증대되고 있다[13-15]. 그러나 그래핀의 전기전도성이 매우 뛰어나다고 할지라도 그래핀이 한 층으로 연속적으로 존재하지 않는다면 투명하면서도 전도성을 띄지 못하게 된다. 그래핀을 한 층으로 존재시키기 위해서는 화학 증착법, 롤투롤법과 같은 매우 고가의 장비가 필요하다. 그래서 그 래핀의 첨가량을 최소한으로 줄이고 전도성을 확보할 수 있는 방안 이 필요하다.

본 연구에서는 투명전도성막을 제조하기 위해서 $\mathrm{BC}$ 막에 홈을 파 서 직교상의 그물모양을 형성한 후, 그래핀과 은 나노와이어를 첨
가하는 방식으로 전도성막을 제조하고자 하였다. 제조된 막의 광학 적, 전기적 물성을 평가하여 플렉서블 투명전극 재료로의 사용가능 성을 검토하고자 한다.

\section{2. 실험재료 및 방법}

\section{2-1. $\mathrm{BC}$ 의 생산}

Acetobacter xylinum KJ1을 BC 생산균주로 사용하여 Glu-Fruc 배지에서 생산하였다 $[6,16]$. 배지의 주 성분은 $0.5 \%(\mathrm{w} / \mathrm{v})$ glucose, $1.5 \%(\mathrm{w} / \mathrm{v})$ fructose, $0.5 \%(\mathrm{w} / \mathrm{v})$ yeast extract, $0.5 \%(\mathrm{w} / \mathrm{v})$ peptone, $0.27 \%$ sodium phosphate $\left(\mathrm{Na}_{2} \mathrm{HPO}_{4}\right), 0.12 \%(\mathrm{w} / \mathrm{v})$ citric acid로 구 성되었고, $1 \mathrm{M} \mathrm{HCl}$ 용액으로 $\mathrm{pH} 5.25$ 로 조정하였다. Acetobacter xylinum KJ1을 Gluc-Fruc 고체배지에서 배양한 colony 한 개를 취 하여 Gluc-Fruc 배지 $100 \mathrm{ml}$ 에 접종한 후 $30{ }^{\circ} \mathrm{C}$ 에서 36 시간 전 배 양하고 이를 homogenizer(Nissei, A-7) $10,000 \mathrm{rpm}$ 에서 $1 \mathrm{~min}$ 동 안 분쇄한 후 본 배양액의 $4 \%$ 로 접종하여 $30^{\circ} \mathrm{C}, \mathrm{pH} 5.25,10$ 일 동 안 정치배양하였다. 생산된 $\mathrm{BC}$ pellicle은 $0.1 \mathrm{M} \mathrm{NaOH}$ 용액에 넣어 $80^{\circ} \mathrm{C}$ 에서 20 분간 끓여 균체를 용해시킨 후, 증류수로 수회 수세하 고 $4{ }^{\circ} \mathrm{C}$ 에서 침지시켜 보관하며 24 시간 단위로 7 일간 증류수를 교 체해 가면서 pellicle이 흰색이 될 때까지 계속 반복 수세한 후 $50{ }^{\circ} \mathrm{C}$ 의 진공 오븐에서 건조시켰다.

\section{2-2. $\mathrm{BC}$ 의 질산화 및 용해}

막을 제조하기 위해서 건조된 $\mathrm{BC}$ 를 질산화처리하여 ethyl acetate 용매에 녹여 용액으로 만들었다. 박테리아 셀룰로오스를 오산화이 인산과 진한 질산의 혼산으로 반응시켜 질산화처리를 하였다. $404 \mathrm{~g}$ 의 $\mathrm{P}_{2} \mathrm{O}_{5}$ 를 $1,000 \mathrm{ml} \mathrm{HNO}$ (백연질산 $90 \%$ )에 천천히 녹인 후 $10 \mathrm{~g}$ 의 $\mathrm{BC}$ 를 $400 \mathrm{~mL}$ 의 질산염 용액에 용해하였다. $20{ }^{\circ} \mathrm{C}$ 에서 $20 \mathrm{~min}$ 반 응시킨 후 증류수로 여러 번 세척하였다. $5 \%$ 의 $\mathrm{Na}_{2} \mathrm{CO}_{3}$ 용액으로 중화시킨 후 증류수로 여러 번 세척하였다. $100{ }^{\circ} \mathrm{C}$ 에서 $20 \mathrm{~min}$ 반 응시키고 물을 제거한 후, Methanol에 10 분간 담갔다 빼서 $50^{\circ} \mathrm{C}$ 에 서 4시간 동안 건조하였다[17]. 완전히 건조된 $\mathrm{BC}$ 막 $5 \mathrm{~g}$ 을 $1 \mathrm{~L}$ 의 ethyl acetate에 gel 상태가 될 때까지 용해시킨다. 용해된 BC 용액은 $2,000 \mathrm{~g}$, $10 \mathrm{~min}$ 간 원심 분리하여 미 용해된 $\mathrm{BC}$ 를 제거하였다.

\section{2-3. 그래핀의 분산}

본 연구에 이용한 그래핀은 일본 (주)인큐베이션 알라이안스에서 3 7겹으로 된 플라워 상태의 그래핀을 구입하여 사용하였다. 뭉쳐 져 있는 그래핀 분말 $20 \mathrm{mg}$ 을 $50 \mathrm{ml}$ 튜브에 넣고 $30 \mathrm{ml}$ 의 Isopropyl alcohol를 넣고 $375 \mathrm{~W}$ 에서 10 분간 초음파처리를 하여 분산시켰다. 이 분산용액을 정치시킨 후 용매는 회수하고 그래핀에 남은 여분의 용매를 증발시킨 후 분말을 회수하여 실험에 이용하였다.

\section{2-4. $\mathrm{AgNW}$ 의 합성}

$\mathrm{AgNW}$ 합성은 polyol process를 이용하였다[18]. Ethylene glycol (EG) $50 \mathrm{ml}$ 을 플라스크에 넣고 $151.5^{\circ} \mathrm{C}$ 에서 1 시간 동안 마그네틱 바로 교반시키면서 가열한 후 $4 \mu \mathrm{M}$ 의 $\mathrm{CuCl}_{2}$ 를 $400 \mu \mathrm{l}$ 첨가하였다. 15 분 후 $0.147 \mathrm{M}$ 의 $\mathrm{PVP}$ 를 $15 \mathrm{ml}$ 을 넣은 후 $0.094 \mathrm{M}$ 의 $\mathrm{AgNO}_{3} 15 \mathrm{ml}$ 을 넣고 $151.5^{\circ} \mathrm{C}$ 에서 1 시간 동안 마그네틱바로 교반시키면서 반응시 켰다. 반응을 멈추기 위해서 반응 플라스크를 실온의 물에 담가 식 혔다. 생산물은 원심 분리하여 침전물을 분리하고 $20 \%$ 의 아세톤용액 
으로 세척한 후 증류수로 상등액이 깨끗해 질 때까지 세척을 하여 $\mathrm{EG}$ 와 PVP를 제거하였다. 최종 산물은 에탄올에 재분산시켜 건조 시킨 후 분말상태의 $\mathrm{AgNW}$ 를 이용하였다.

\section{2-5. $\mathrm{BC}$ 막의 제조}

질산화 처리된 $\mathrm{BC}$ 를 ethyl-acetate에 녹일 때 $\mathrm{BC}$ 의 용해도가 약 $5 \mathrm{~g} / \mathrm{L}$ 이므로 $\mathrm{BC}$ 의 농도를 높이기 위해서 감압 증발증류기를 이용 하여 ethyl-acetate를 증발시켜 농도를 향상시켰다. $\mathrm{BC}$ 용액을 $10,000 \mathrm{rpm}, 10 \mathrm{~min}$ 원심분리하여 덜 용해된 $\mathrm{BC}$ 를 제거한 후 증류 비커에 넣고 감압 증류하여 $\mathrm{BC}$ 를 농축하였다. 준비된 높이 $12 \mathrm{~cm}$ 의 스테인리스 용기에 $\mathrm{BC}$ 용액을 $100 \mathrm{~g}(\mathrm{wt})$ 씩 담은 후 $70 \mathrm{~W}, 10 \mathrm{~min}$ 간 초음파 처리를 실시하여 용액 내의 기포를 제거하였다. 급속한 증발에 따른 막의 일그러짐을 예방하기 위해서 세 겹으로 겹친 거 즈를 이용하여 용기의 윗부분을 덮고 실온의 hood 내에서 서서히 건조시킨 후 막을 용기에서 분리하여 $2 \times 2(\mathrm{~cm})$ 로 자르고 $2 \mathrm{~mm}$ 간 격으로 칼을 이용하여 홈을 팠다. 준비된 a) 순수한 $\mathrm{BC}$ 막, b) $\mathrm{AgNW}, \mathrm{c}) \mathrm{AgNW}$ 와 graphene 혼합한 것, d) graphene을 채워서 제 조한 막과, PEDOT:PSS 고분자로 홈을 채운 후 e) $\mathrm{AgNW}, \mathrm{f}$ ) $\mathrm{AgNW}$ 와 graphene 혼합한 것, g) graphene을 채우는 방식으로 총 7 가지 패턴으로 막을 제조하였다. AgNW와 graphene의 혼합 비율 은 1:1(각각 $20 \mathrm{mg}$ )로 제조하여 막에 충진시켰으나 두 물질의 구조 적 차이로 인하여 최종적으로 채워진 양은 정밀하게 측정하지 못하 였다.

\section{2-6. $\mathrm{BC}$ 막과 $\mathrm{PET}$ 의 열적안정성}

질산화 시킨 박테리아 셀룰로오스 막과 PET[poly(ethylene terephthalate)]의 열적 안정성을 비교 평가하기 위하여 hot plate를 $150 \pm 5{ }^{\circ} \mathrm{C}$ 로 가열한 후 각각 $2 \times 4 \mathrm{~cm}$ 로 절단한 $\mathrm{BC}$ 막과 $\mathrm{PET}$ 를 hot plate에 올려놓고 15 초간 가열 후 변화된 모습을 사진으로 촬영하였 다. 또한, DSC 2920 (Differential scanning Calorimeter) 기기를 통 하여 온도조절 프로그램으로 $\mathrm{BC}$ 막과 $\mathrm{PET}$ 에 온도 변화를 주어 $\mathrm{BC}$ 막과 $\mathrm{PET}$ 가 가지고 있는 물리적 온도 특성을 관찰하였다. 분석조 건으로는 Temperature range : $25 \sim 400{ }^{\circ} \mathrm{C}$, Heating rate : $20{ }^{\circ} \mathrm{C} / \mathrm{min}$, Air : $\mathrm{N}_{2}$ 로 측정하였다.

\section{2-7. UV-VIS-NIR 측정}

제조한 막의 투명도를 측정하기 위하여 Hitachi 사의 U-3501을 이용하여 400 $800 \mathrm{~nm}$ 까지의 광투과도를 측정하였다. 대조군으로는 순수 $\mathrm{BC}$ 막을 이용하였다.

\section{2-8. SEM 분석}

제조한 막의 표면은 전계방출주사전자현미경 Cold Field Emission Scanning Electron Microscope (제조사 : Hitachi, Japan), Model : S-4700을 이용하여 관찰하였다. 용이한 관찰을 위해서 시료를 알루 미늄 원판 위에 carbon tape를 이용하여 고정시켜 관찰하였다.

\section{2-9. Hall effect (전자농도, 전자이동도, 비저항) 측정}

제조된 막의 두께를 측정하기 위해서 Digital micrometer (Mitutoyo) 를 이용하였다. 또한 막의 전기적 특성을 평가하기 위해서 Hall effect measurement system $(\mathrm{EQK})$ 을 이용하여 다양하게 제조된 전도성 막의 전자농도, 전자이동도 및 비저항을 측정하였다.

\section{2-10. LED 전구 점등 실험}

직류 안정화 전원공급기(Regulated DC power supply; Provice)를 이용하여 2 $10 \mathrm{~V}$ 의 전압을 걸고 7가지의 막에 대한 $\mathrm{LED}$ 전구 점 등 실험을 실시하였다. 제조된 막은 평면의 경우와 유연하게 구부 린 경우의 두 가지 상태에 대하여 측정하였다.

\section{3. 결과 및 고찰}

\section{3-1. 합성된 막의 구조 및 특성 분석 결과}

3-1-1. BC막의 제조

질산화 처리방법으로 박테리아 셀룰로오스를 처리하여 ethyl acetate에 겔 상태로 용해를 시킨 후, 막의 두께 315 380 $\mu \mathrm{m}$ 의 범 위로 막을 제조하였다. 기포 흔적이 없는 표면이 매끄러운 막을 제 조하기 위해서 $70 \mathrm{~W}, 10 \mathrm{~min}$ 간 초음파의 degasing 처리를 실시하 여 용액 내의 기포를 제거하였다. 또한 용매의 급속한 증발에 따른 막의 표면의 굴곡을 예방하기 위해서 세 겹으로 겹친 거즈를 이용 하여 용기의 윗부분을 덮고 실온의 hood 내에서 서서히 건조시켰다. 완전히 건조된 막을 용기에서 분리하여 용도별로 $2 \times 4(\mathrm{~cm})$, $2 \times 2.5(\mathrm{~cm}), 2 \times 2(\mathrm{~cm})$ 의 크기로 잘랐다. 막은 표면이 매끄러우며 플 라스틱 질감의 견고한 막으로 형성되었다.

\section{3-2. BC와 PET의 열적 안정성평가}

본 연구에서는 투명전도성막의 기반물질로 물리적 강도가 뛰어 난 친환경 바이오 플라스틱 소재인 $\mathrm{BC}$ 를 이용하고자 한다. 기존에 이용되고 있는 PET와의 열적인 안정성을 비교 평가하기 위하여 hot plate를 $150 \pm 5^{\circ} \mathrm{C}$ 로 가열한 후 각각 $2 \times 4 \mathrm{~cm}$ 로 절단한 $\mathrm{BC}$ 막과 $\mathrm{PET}$ 를 hot plate에 올려놓고 15 초간 가열 후 변화된 모습을 사진으로 촬영 하였다(Fig. 1). 그림에서와 같이 $\mathrm{BC}$ 막은 고온에서도 형태의 변화 가 전혀 일어나지 않았으나 PET의 경우 열판에 올려놓자마자 형태 가 심하게 변형되어 일그러진 것을 확인할 수 있었다. PET의 경우 유리 전이 온도가 $73^{\circ} \mathrm{C}$, 연화 온도가 $170{ }^{\circ} \mathrm{C}$ 으로 고온에서 열적 안 정성이 매우 떨어진다. 반면에 $\mathrm{BC}$ 막은 $150{ }^{\circ} \mathrm{C}$ 의 고온에서도 매우 안정된 상태로 유지되는 것을 알 수 있다. DSC 분석결과 PET는 유 리 전이온도가 $75^{\circ} \mathrm{C}$ 부근이었고 $128.41^{\circ} \mathrm{C}$ 에서 모두 소멸되었으며, $\mathrm{BC}$ 의 경우 형태 변화 없이 $208.97{ }^{\circ} \mathrm{C}$ 에서 소멸되는 결과를 얻었다 (Data not shown). 이 결과로부터 $\mathrm{BC}$ 를 투명전도성 막에 적용시킬 경우 고온에서의 전자기기의 안정적인 작동을 확보할 수 있을 것으 로 사료된다.

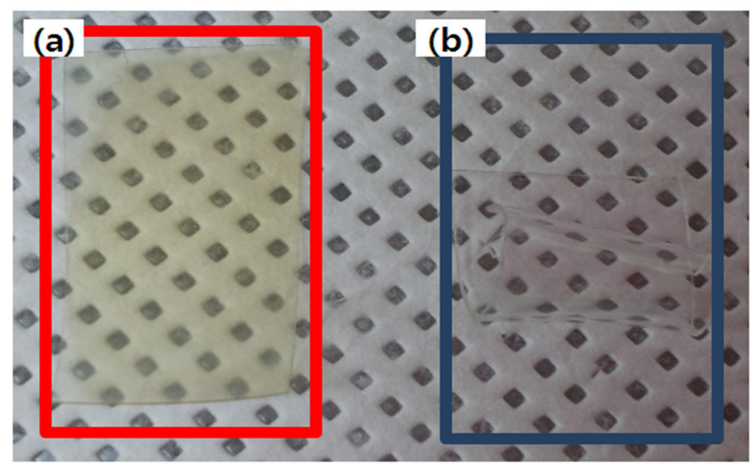

Fig. 1. The thermal stability test of $B C(a)$ and PET(b) films at $150 \pm 5^{\circ} \mathrm{C}$. 


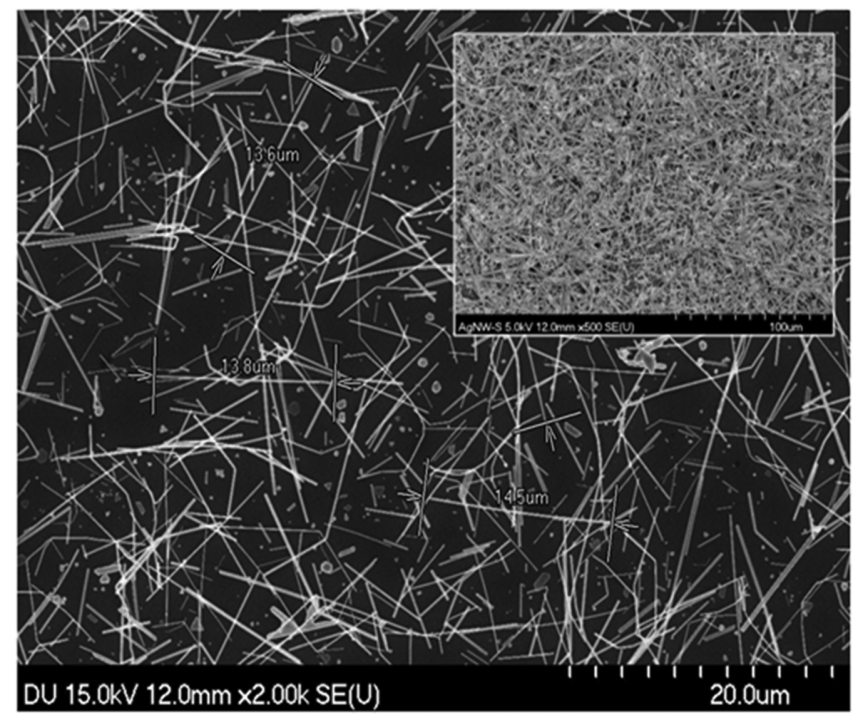

Fig. 2. SEM image of the synthesized AgNW.

\section{3-3. AgNW 합성}

$\mathrm{BC}$ 막의 전도성을 확보하기 위해서 $\mathrm{AgNW}$ 를 직접 합성하여 사 용하였다. 소량의 $\mathrm{AgNW}$ 는 매우 고가에 판매되고 있으므로 실험에 이용한 충분한 양을 확보하기 위해서 실험실에서 직접 합성하여 사 용하였다. 합성방법으로는 Polyol process[18]를 합성 용매의 첨가 방법을 기존의 실린지 펌프를 이용하던 것을 피펫으로 첨가하는 방 법을 이용하였다. 개량한 방법으로 합성하였을 때 $\mathrm{AgNW}$ 의 뭉침 현상이 적고 비교적 양호한 상태로 합성되는 것을 확인하였다. SEM 이미지를 통해 확인 할 수 있듯이 합성된 $\mathrm{AgNW}$ 는 평균적으로 길 이 약 $15 \mu \mathrm{m}$, 폭 약 $70 \mathrm{~nm}$ 로 종횡비 214이었다(Fig. 2). $\mathrm{AgNW}$ 는 종횡비가 클수록 상호 연결성이 뛰어나 접촉저항을 낮추어 전도성 을 개선시키게 된다[11].

\section{3-4. $\mathrm{BC}$ 를 이용한 다양한 전도성 투명막의 제조}

$\mathrm{BC}$ 막은 완벽한 절연체의 물질이다. 그러므로 막의 전도성을 확 보하기 위해서 전도성이 매우 뛰어난 물질인 $\mathrm{AgNW}$ 와 graphene을 이용하여 전극을 형성하였다. 투명성을 확보하기 위해서는 직교상 의 그물망으로 제조를 하는 것이 효율적이다. 기존의 다른 연구에
서는 금속 그리드를 적용하여 제작하는 방법, 스탬프를 제작하여 찍 는 방법 등을 이용하였으나 본 연구에서는 실험실적 상황을 고려하 여 저비용으로 간단하게 격자모양을 형성하였다. 전극 형성 방법으 로는 제조된 막을 $2 \times 2 \mathrm{~cm}$ 로 자른 후, 막의 표면에 칼을 이용하여 $2 \mathrm{~mm}$ 간격으로 홈을 파서 $\mathrm{AgNW}, \mathrm{AgNW}$ 와 graphene 혼합한 것, graphene을 홈에 채워서 제조하였다. 또한 전도성 고분자인 PEDOT:PSS를 칼 날에 묻힌 후, 홈에 채우고 $\mathrm{AgNW}, \mathrm{AgNW}$ 와 graphene 혼합한 것, graphene을 채워 막을 제조하였다. 이와 같은 방식으로 총 7가지 패 턴으로 막을 제조하였다(Fig. 3). 투명막의 크기는 대면적으로 성형 이 가능하며 정교한 기계적인 작업으로 전환한다면 일정한 굵기로 더욱 미세한 전극을 형성할 수 있을 것이다. 또한, 충진되는 전도성 물질의 양이나 채워진 양상에 따라 전도성에 크게 영향을 끼치므로 기계적으로 정밀하게 제어하는 것이 무엇보다 중요할 것이다. 전도 성 고분자인 PEDOT:PSS를 적용할 경우에도 극히 미량으로 치밀 하고 번짐없이 홈에 바르고 전도성 물질을 부착시킬 수 있다면 전 도성 물질의 탈락이 없이 광투과성이 뛰어나며 전기적 특성이 우수 한 투명전극을 생산할 수 있을 것으로 사료된다.

\section{3-5. 광투과도 분석}

제조된 막의 가시광선 파장인 $550 \mathrm{~nm}$ 에서의 광투과도를 측정한 결과 Table 1과 Fig. 4에서와 같이 $\mathrm{AgNW}$ 의 경우 $98.1 \%$ 로 가장 뛰 어난 투과도를 나타냈으며 graphene의 경우 $80.9 \%$ 를 나타내었다. 그러나 $\mathrm{AgNW}$ 와 graphene 혼합한 것을 채운 것은 $77.6 \%$ 로 가장 낮은 흡광도를 나타내었다. $\mathrm{AgNW}$ 와 graphene이 혼합될 경우 공극 과 공극을 더욱 치밀하게 채우게 되어 빛의 투과도를 떨어뜨리는 것 으로 사료된다. 또한 접착력 확보와 전도성 향상을 위한 목적으로 전도성 고분자인 PEDOT:PSS를 바른 경우에는 바르지 않은 경우 보다 광투과도가 현저하게 떨어지는 것을 확인하였다. 이는 PEDOT:PSS가 청색의 고유 색깔을 지니고 있기 때문으로 판단된다. 실험 결과에서 $\mathrm{AgNW}$ 의 경우 $68.3 \%$, graphene의 경우 $41.2 \%, \mathrm{AgNW}$ 와 graphene 혼합하여 채운 것은 $37.9 \%$ 로 가장 낮은 값을 나타내 었다(Fig. 4). 광투과성이 크게 저하되는 이유로는 PEDOT:PSS를 바르는 과정에서 칼날을 이용하여 바르는 작업으로 인해 홈에 세밀 하게 채워 넣지 못하고 막의 표면에 번지게 되어 전도성 물질이 홈 뿐만 아니라 막의 표면까지 부착되었기 때문으로 생각된다. 이러한 문제점을 해결하기 위해서는 마이크로 혹은 나노미터 단위로 홈을

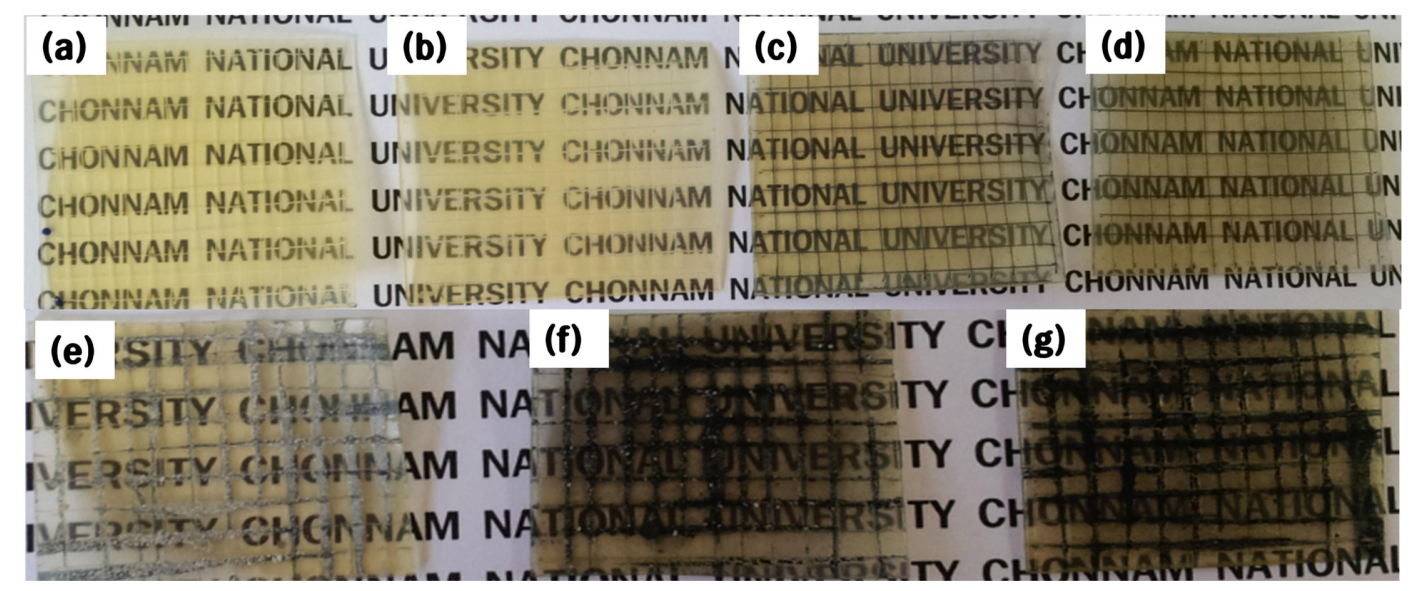

Fig. 3. Photos of the various films (a; BC, b; BC + AgNW, c; BC + AgNW + graphene, d; BC + graphene, e; BC + AgNW + PEDOT, f; BC + AgNW + graphene + PEDOT, g; BC + graphene + PEDOT). 
Table 1. Thickness, optical transmittance, electron concentration, electron mobility, resistivity and sheet resistance of fabricated films

\begin{tabular}{|c|c|c|c|c|c|c|}
\hline & $\begin{array}{l}\text { Thickness } \\
(\mu \mathrm{m})\end{array}$ & $\begin{array}{l}\text { Transmittance } \\
(550 \mathrm{~nm}) \%\end{array}$ & $\begin{array}{l}\text { Electron Concentration } \\
\left(1 / \mathrm{cm}^{3}\right)\end{array}$ & $\begin{array}{l}\text { Electron Mobility } \\
\left(\mathrm{cm}^{2} / \mathrm{Vs}\right)\end{array}$ & $\begin{array}{l}\text { Resistivity } \\
(\Omega \cdot \mathrm{cm})\end{array}$ & $\begin{array}{c}\text { Sheet resistance } \\
(\Omega / \mathrm{sq} .)\end{array}$ \\
\hline $\mathrm{a}$ & 325 & - & - & - & - & \\
\hline b & 350 & 98.1 & $1.53 \times 10^{19}$ & $6.63 \times 10^{5}$ & 0.28 & 8.00 \\
\hline $\mathrm{c}$ & 340 & 77.6 & $5.60 \times 10^{15}$ & 21.68 & 5.14 & 151.18 \\
\hline d & 360 & 80.9 & $7.74 \times 10^{17}$ & 0.17 & 4.78 & 132.78 \\
\hline e & 340 & 68.3 & $2.02 \times 10^{19}$ & 4.05 & 7.65 & 225.00 \\
\hline g & 315 & 41.2 & $1.74 \times 10^{15}$ & 31.32 & 11.49 & 364.76 \\
\hline
\end{tabular}

a:BC, b: BC+AgNW, c: BC+AgNW+Graphene, d: BC+Graphene, e: BC+AgNW+PEDOT, f: BC+AgNW+Graphene+PEDOT, g: BC+Graphene+PEDOT

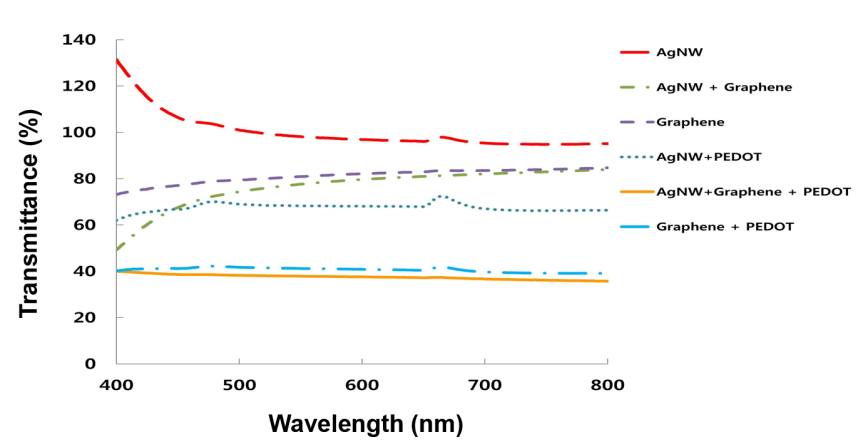

Fig. 4. Light transmittance spectra of the various films in the visible light region.

파고 그 홈에 PEDOT:PSS와 같은 접착성이 있는 물질과 전도성 물 질 $(\mathrm{AgNW}, \mathrm{graphene}$ 등)과 혼합하여 채우는 정밀한 기계적 작업으 로 가능할 것으로 생각된다. 본 연구에서 제조한 막의 두께가 가장 얇게는 315 에서 두꺼운 것은 $380 \mu \mathrm{m}$ 로 일정하지 않았다. 막의 두
께에 따라서 광투과도에 영향을 끼칠 것으로 예상되나 막을 제조함에 있어서 기계적인 방법이 아니었기에 정밀한 제어에 한계가 있었다.

\section{3-6. SEM 분석}

제조된 막을 $\mathrm{SEM}$ 이미지를 통해 홈의 폭과 전도성 물질이 채워 진 양상을 살펴보았다. 삽입된 사진(Fig. 5)은 각 막의 홈을 확대하 여 관찰한 사진이다. 사진에서와 같이 홈의 폭은 $65 ~ 75 \mu \mathrm{m}$ 이었으 며, 격자상으로 파인 홈에 $\mathrm{AgNW}$ 및 graphene이 채워져 있는 것을 확인할 수 있다. 그러나 PEDOT:PSS를 바른 쪽은 바르는 과정에서 정교하지 못하여 홈과 그 주변까지 전도성 물질이 달라붙어 지저분 하게 형성되었다. 이로 인하여 광투과도를 크게 저하시키게 되었 다. 홈의 깊이와 폭이 정교하게 제어되지 못한 결과 홈에 채워진 $\mathrm{AgNW}$ 와 graphene의 양과 혼합 비율이 정밀하지 않아서 일정한 전기적 특성을 확보하는데 걸림돌이 되었을 것이다. 실제로 적용 하기 위해서는 홈의 깊이와 폭의 균일성 확보가 매우 중요할 것 이다.

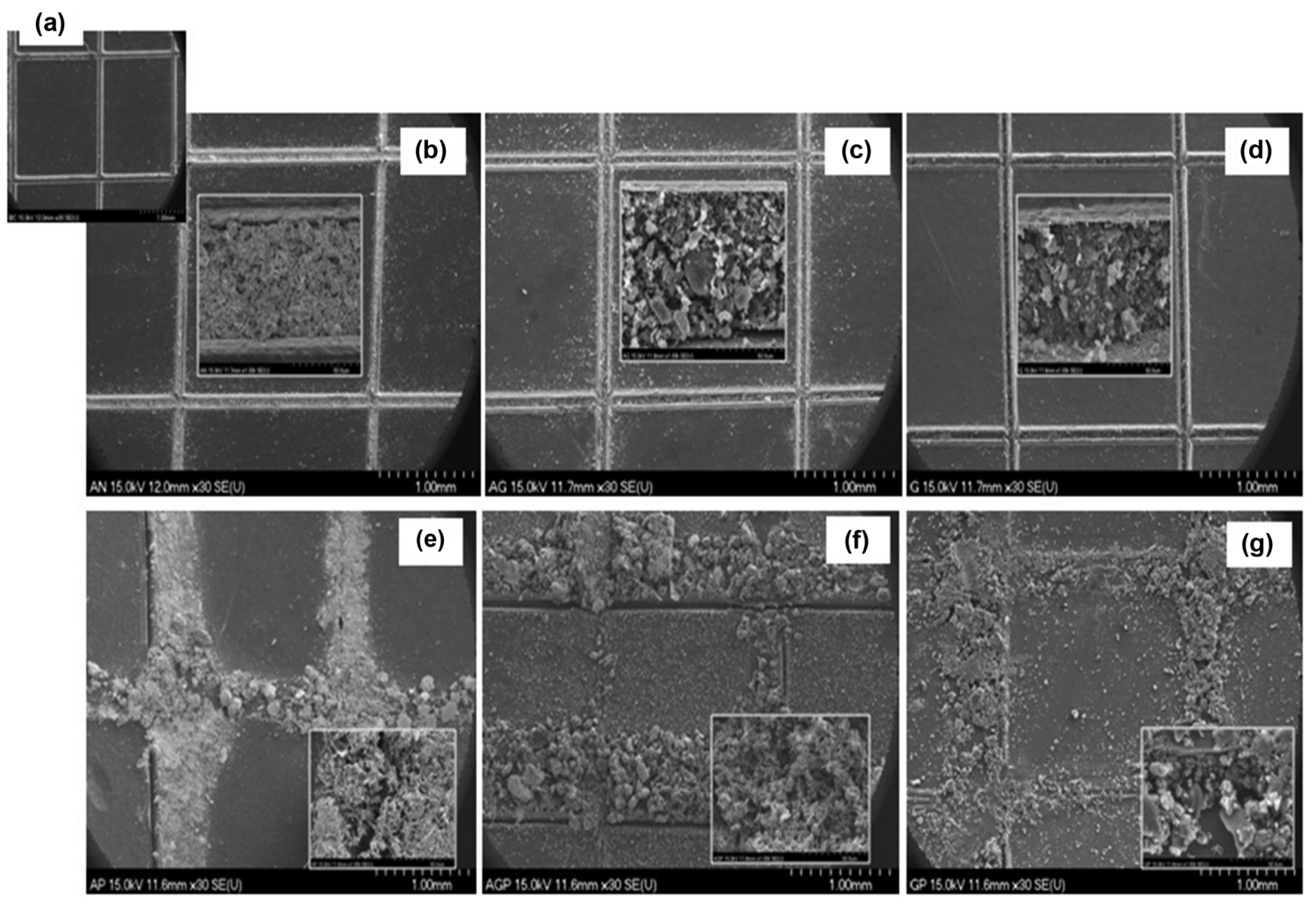

Fig. 5. SEM images of the various films (a; BC, b; BC + AgNW, $\mathrm{c} ; \mathrm{BC}+\mathrm{AgNW}+$ graphene, d; BC + graphene, e; BC + AgNW + PEDOT, f; BC + AgNW + graphene + PEDOT, g; BC + graphene + PEDOT).

Korean Chem. Eng. Res., Vol. 51, No. 6, December, 2013 


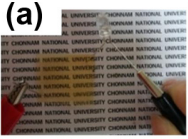
PSTIY CHONNAM NATIONAL UN ERSITY CHONNAM NATIONAL UNI

(b)

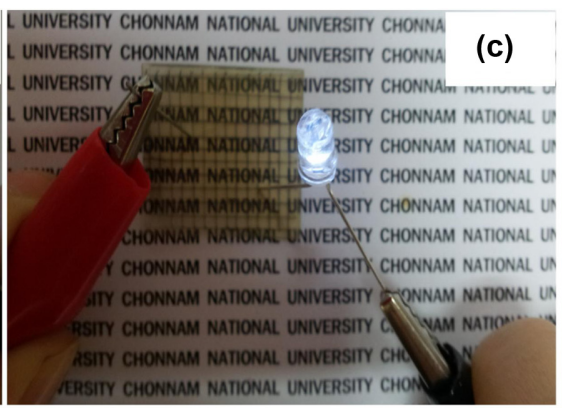

SITY CHONNAM NATIONAL UNIVERSTYY CHONN

UNIVERITY CHONN SITY CHONNAM NATIONAL UNIVERSITY CHONN $/$ (e)

SITY CHONNAM NATIONAL UNIVERS 'HONN/

(e)

SITY CHONNAM NATIONAL UNIVERS ;HONNAM NATIONAL SITY CHONNAM NATIONAL UNIVERS ZHONNAM NATIONAL

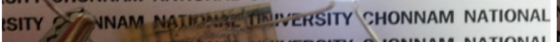

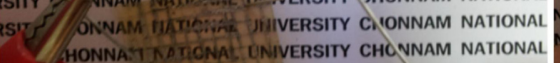

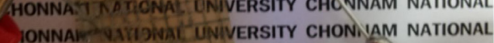

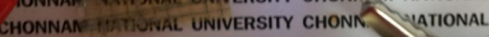
CHONNAM NATIONAL. UNIVERSITY CHONNAN

TY CHONNAM NATIONAL. UNIVERSITY CHONNAM

ISITY CHONNAM NATIONAL UNIVERSITY CHONNAM N

RSITY CHONNAM NATONAL. UNIVERSITY CHONNAM N

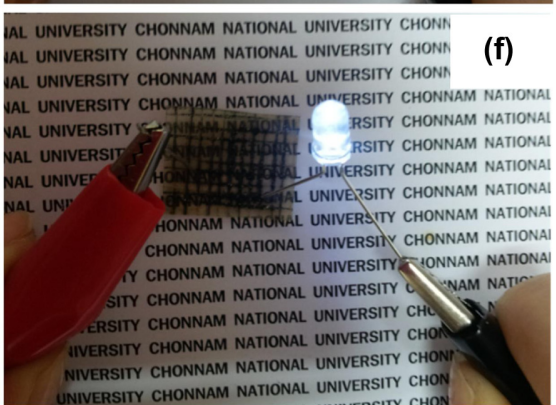

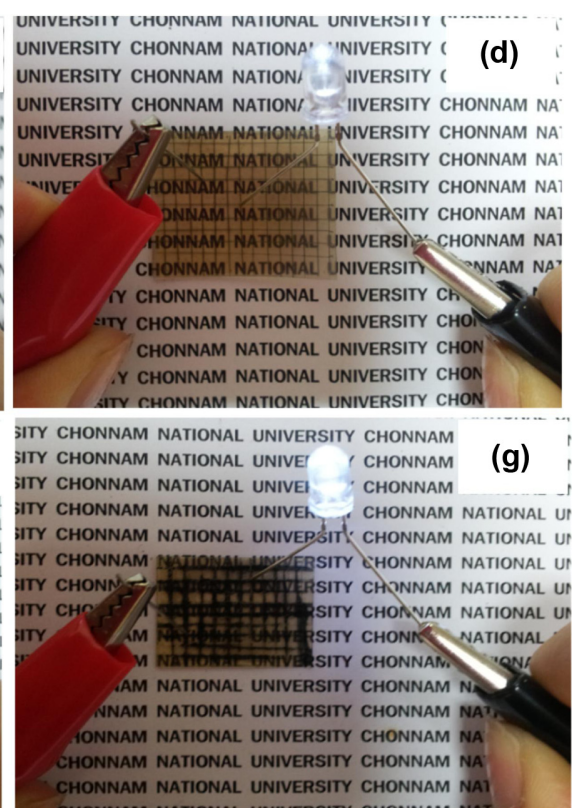

Fig. 6. Photos of the LED bulbs lighting test in plane condition (a; BC, b; BC $+\mathrm{AgNW}, \mathrm{c} ; \mathrm{BC}+\mathrm{AgNW}+$ graphene, d; $\mathrm{BC}+\mathrm{graphene}$, e; $\mathrm{BC}$ + AgNW + PEDOT, f; BC + AgNW + graphene + PEDOT, g; BC + graphene + PEDOT).
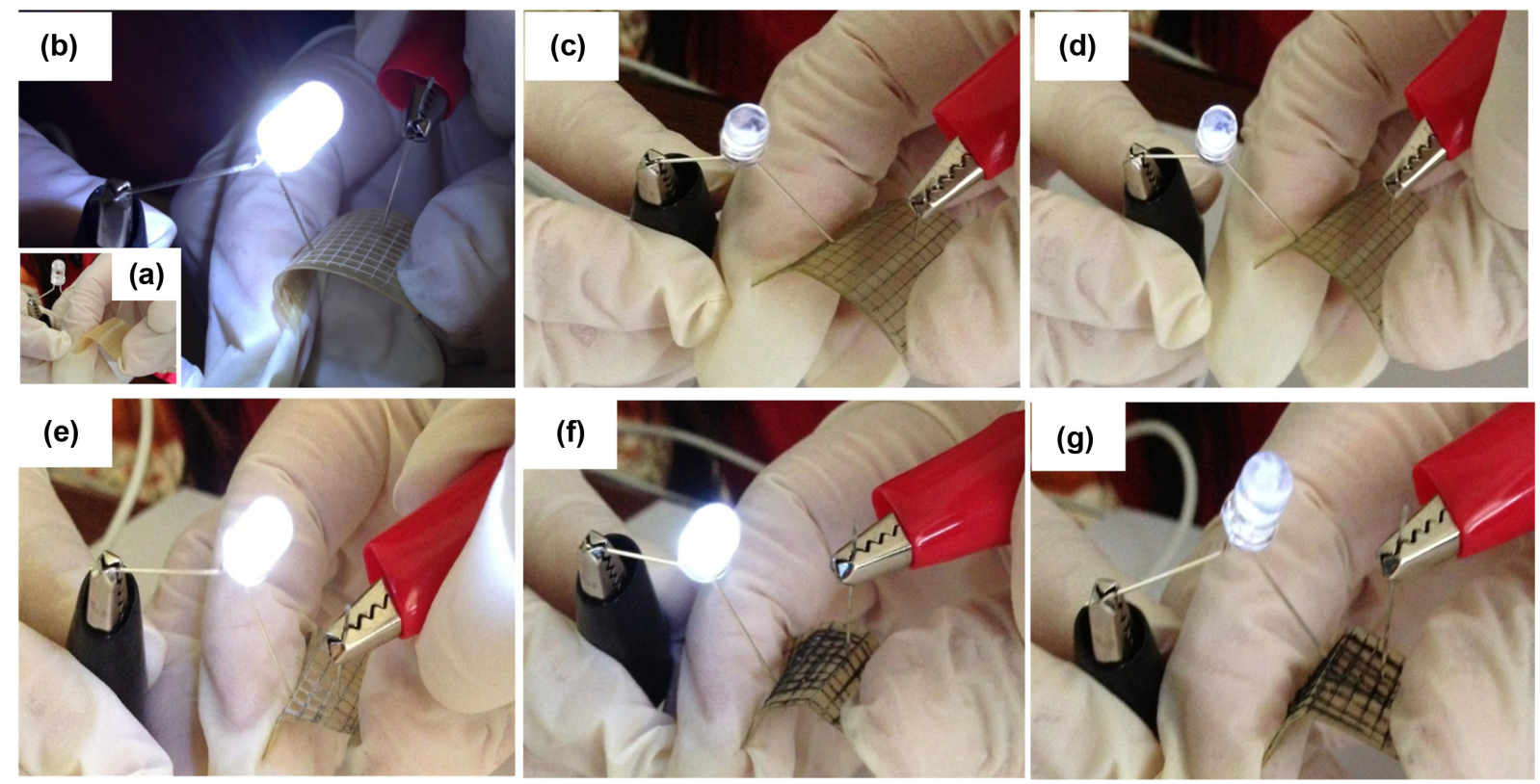

Fig. 7. Photos of the LED bulbs lighting test in bent condition $(\mathrm{a} ; \mathrm{BC}, \mathrm{b} ; \mathrm{BC}+\mathrm{AgNW}, \mathrm{c} ; \mathrm{BC}+\mathrm{AgNW}+\mathrm{graphene}, \mathrm{d} ; \mathrm{BC}+\mathrm{graphene}, \mathrm{e} ; \mathrm{BC}+$ AgNW + PEDOT, f; BC + AgNW + graphene + PEDOT, g; BC + graphene+ PEDOT).

\section{3-7. 합성된 막의 전기적 특성 분석 결과}

3-7-1. LED 전구 점등 실험

다양한 방법으로 제조한 전도성막의 전도성을 확인하기 위하여 직류전원 공급기를 이용하여 LED 전구의 점등 실험을 실시하였다. Fig. 6, 7에서와 같이 전도성 물질을 채워 넣은 막의 경우 모두 LED 전구가 점등되었다. 실험은 막을 평면 상태로 한 것과 유연하게 휜 상태로 평가하였다. 삽입된 사진의 $\mathrm{BC}$ 로만 구성된 막은 $\mathrm{LED}$ 전구 에 불이 들어오지 않았으나, 다른 막은 모두 불이 켜진 것을 확인할 수 있다. 그러나 막의 종류에 따라 전구의 밝기에 차이가 있었다. $\mathrm{AgNW}$ 를 채운 막은 $4 \mathrm{~V}$ 의 전압 인가시 매우 강한 빛으로 LED 전
구에 불이 들어왔다. 그 외의 막은 $\mathrm{AgNW}$ 에 PEDOT:PSS를 바른 것을 제외한 나머지 막에서는 PEDOT:PSS를 바른쪽이 그렇지 않 은 쪽에 비해 전구의 빛이 밝았다. 이 결과는 유연하게 휜 상태에서 도 마찬가지 결과였다. 이는 PEDOT:PSS가 전도성 고분자이므로 전류의 흐름을 원활하게 하였을 가능성도 있지만, SEM 사진에서 본 것과 같이 많은 양의 전도성 물질(AgNW와 graphen)이 분포하 여 전구의 밝기에 영향을 끼친 것으로 생각된다. 그러나 $\mathrm{AgNW}$ 의 경우에는 PEDOT:PSS를 적용한 쪽이 전구의 밝기가 더 낮았다. 그 이유로는 순수한 $\mathrm{AgNW}$ 만을 적용한 쪽이 $\mathrm{AgNW}$ 에 비해 상대적으 로 전기적 물성이 떨어지는 PEDOT:PSS의 방해없이 네트워크를 
형성하였기에 전류 흐름이 더욱 원활히 이루어져 나타난 결과로 생 각된다. 더 자세한 전기적 특성을 파악하기 위해서 반도체 Hall effect 측정 장비를 이용하여 전기농도, 전기이동도, 비저항 등을 측 정하였다.

\section{3-7-2. 전기적 특성 평가}

다양한 막의 전기적 특성을 파악하기 위해서 반도체 Hall effect를 측정하는 장비를 이용하여 평가하였다. 이 측정으로부터 전기농도, 전기이동도, 비저항을 구할 수 있는데 전기농도와 전기이동도의 값 이 클수록 비저항 값이 작을수록 전기적 물성이 뛰어난 것으로 판 단할 수 있다. 막의 두께는 Table 1 에서와 같이 막의 종류에 따라 두께에 차이가 있었다. 실험 결과로부터 $\mathrm{AgNW}$ 를 적용한 막이 가 장 뛰어난 전기적 물성을 지닌 것으로 평가되었다. $\mathrm{AgNW}$ 첨가막은 두께 $350 \mu \mathrm{m}$, 전자농도 $1.53 \times 10^{19} / \mathrm{cm}^{3}$, 전자이동도 $6.63 \times 10^{5} \mathrm{~cm}^{2} / \mathrm{Vs}$, 비저항 $0.28 \Omega \cdot \mathrm{cm}$ 로 가장 우수한 전기적 특성을 지닌 것으로 평가 되었다. 그래핀 첨가막은 두께 $360 \mu \mathrm{m}$, 전자농도 $7.74 \times 10^{17} / \mathrm{cm}^{3}$, 전 자이동도 $0.17 \mathrm{~cm}^{2} / \mathrm{Vs}$, 비저항 $4.78 \Omega \cdot \mathrm{cm}$ 로 평가되었다. 두 막의 표면저항 값을 토대로 전기적 특성을 비교할 때 $\mathrm{AgNW}$ 첨가막이 graphene 첨가막에 비해 약 17 배 뛰어난 것으로 판단된다. 플렉서 블 투명전극 재료로 사용되기 위해서는 가시광영역 $(400 \sim 700 \mathrm{~nm})$ 에 서 $80 \%$ 의 광투과도를 가지며 $\sim 10^{3} \Omega / \mathrm{sq}$. 이하의 높은 전기전도성 을 가져야만 한다. 이에 $\mathrm{AgNW}$ 첨가막의 면저항값이 $8.0 \Omega / \mathrm{sq}$. 이고 graphene 첨가막이 $132.78 \Omega / \mathrm{sq}$.이었다. 그러므로 $\mathrm{BC}$ 막을 기 반으로 하여 $\mathrm{AgNW}$ 및 graphene을 전도성 물질로 전극을 형성한 투명전도성막은 플렉서블 투명전극으로 이용될 가능성이 높다고 할 수 있다. 본 연구에서 제작하는 방법은 매우 간단한 방법으로 막을 제조하였지만, 전기적 특성은 충진 되는 $\mathrm{AgNW}$ 및 graphene의 양 에 따라 달라지게 된다. 그러므로 전기적 특성의 일관성을 얻기 위 해서는 정밀한 제어가 필수적이다. 그러므로 과학적이고 정밀한 기 계적인 가공처리가 적용된다면 우수한 전기적 물성과 투명성을 확 보한 막을 개발할 수 있을 것이다. 게다가 $\mathrm{BC}$ 기반으로 할 경우 인 장강도 및 열적 안정성이 매우 뛰어나며 친환경 소재로서 생분해 가 능하다는 것도 장점으로 적용될 것이다.

\section{4. 결 론}

본 연구에서는 투명전극에 이용되고 있는 PET와 실리콘을 대신 하여 친환경소재인 박테리아 셀룰로오스를 기반으로 한 투명 전도 성막을 제조하였다. $\mathrm{BC}$ 막을 칼로 홈을 파서 직교상의 그물모양을 형성한 후 이 홈에 $\mathrm{AgNW}$ 와 그래핀을 채워 넣는 방법을 적용하였다. $550 \mathrm{~nm}$ 의 가시광선 광투과도 평가결과 $\mathrm{AgNW}$ 첨가막은 $98.1 \%$, 그 래핀 첨가막 $80.9 \%$ 를 확보할 수 있었다. 제조된 막은 평면과 휜 상 태에서 LED 점등 실험에서 전구의 밝기에 차이가 있었으나 불이 켜 졌다. 열적 안정성을 평가하기 위한 $150 \pm 5^{\circ} \mathrm{C}$ 의 열판에서 박테리아 셀룰로오스 막은 형태가 매우 안정하였으나 같은 두께의 PET는 형 태가 심하게 변형되었다. $\mathrm{AgNW}$ 와 그래핀을 첨가하여 제조된 막은 플렉서블 투명전극 재료로서 가시광영역 $(400 ~ 700 \mathrm{~nm})$ 에서 $80 \%$ 이 상의 광투과도를 가지며 제조된 모든 막은 모두 $364.76 \Omega / \mathrm{sq}$. 이하의 높은 전기 전도성을 보였다. 이러한 결과를 통해 박테리아 셀룰로오 스를 기반으로 하는 투명전도성 막을 제조할 수 있는 가능성을 확 인하였다.

\section{감 사}

본 연구는 2013년도 정부의 재원으로 한국연구재단의 중견연구 자지원사업-도약연구의 지원(No.2013-0764)과 2013년도 지역대학 우수과학자 지원사업의 지원(No.2012R1A1A401014339)을 받아 수행된 연구이며 이에 감사를 드립니다.

\section{References}

1. Catrysse, P. B. and Fan, S., "Nanopatterned Metallic Films for Use As Transparent Conductive Electrodes in Optoelectronic Devices,' Nano Lett., 10, 2944-2949(2010).

2. Kuang, P., Park, J. M., Leung, W., Mahadevapuram, R. C., Nalwa, K. S., Kim, T. G., Chaudhary, S., Ho, K. M. and Constant, K. A., "New Architecture for Transparent Electrodes: Relieving the Trade-Off Between Electrical Conductivity and Optical Transmittance," Adv. Mater., 23, 2469-2473(2011).

3. Kang, M. G.; Kim, M. S.; Kim, J. and Guo, L. J., "Organic Solar Cells Using Nanoimprinted Transparent Metal Electrodes," $A d v$. Mater, 20, 4408-4413(2008).

4. Cannon, R. E. and Anderson, S. M., "Biogenesis of Bacterial Cellulose,' Crit. Rev. Microbiol., 17, 435-447(1991).

5. Klemm, D., Schumann, D. Udhard, U. and Marsch, S., "Bacterial Synthesized Cellulose-artificial Blood Vessels for Microsurgery,' Prog. Polym. Sci., 26, 1561-1603(2001).

6. Moon, S. H., Park, J. M., Chun, H. Y. and Kim, S. J., "Comparisons of Physical Properties of Bacterial Cellulose Produced in Different Culture Conditions Using Saccharified Food Wastes,' Biotech. Bioprocess. Eng., 11, 26-31(2006).

7. Granqvist, C. G. and Hultaker, A., "Transparent and Conducting ITO Films; New Developments and Application," Thin Solid Films, 411, 1-5(2002).

8. Hoffman, R. L., Norris, B. J. and Wager, J. F., "ZnO-based Transparent Thin-film Transistors,' Appl. Phys. Lett., 82, 735-733 (2003).

9. Seo, S. W., Won, S. H., Chae, H. Y. and Cho, S. M., "Low-temPerature Growth of Highly Conductive and Transparent Aluminum-doped ZnO Film by Ultrasonic-mist Deposition,' Korean J. Chem. Eng., 29, 525-528(2012).

10. Seo, S. J., Choi, C. G., Hwang, Y. H. and Bae, B. S., "High Performance Solution Processed Amporphous Zinc Tin Oxide Thin Film Transistor,' J. Phys, D: Appl. Phys. 42, 035106(2009).

11. Linsebigler, A. L., Lu, G. Q. and Yates, Jr., J. T., "Photocatalysis on $\mathrm{TiO}_{2}$ Surfaces: Principles, Mechanism, and selected Results," Chem. Rev., 95, 735-758(1995).

12. Choi, J. S., Sauer, G., Nielsch, K., Wehrspohn, R. B. and Gösele, U., "Hexagonally Arranged Monodisperse Silver Nanowires with Adjustable Diameter and High Aspect Ratio,' Chem. Mater., 15, 776-779(2003).

13. Geim, A. K. and Novoselov, K. S., "The Rise of Graphene,' Nat. Mater., 6, 183(2007).

14. Berger, C., Song, Z., Li, T., Li, X., Ogbazghi, A. Y., Feng, R., Dai, Z., Marchenkov, A. N., Conrad, E. H., First, P. N. and Heer, W. A., "Ultrathin Epitaxial Graphite: 2D Electron Gas Properties and a Route toward Graphene-based Nanoelectronics,' J. Phys. Chem. B, 108, 19912-19916(2004). 
15. Ramanathan, T., Abdala, A. A., Stankovich, S., Dikin, D. A., Herrera-Alonso, M., Piner, R. D., Adamson, D. H., Schniepp, H. C., Chen, X., Ruoff, R. S., Nguyen, S. T., Aksay, I. A., Prud'Homme, R. K. and Brinson, L. C., "Functionalized Graphene Sheets for Polymer Nanocomposites,' Nat. Nanotechnol., 3, 327-331(2008).

16. Yim, E. C., Kim, S. J., Oh, I. K. and Kee, C. D., "Plasma Surface Modification of Graphene and Combination with Bacteria Cellulose,' Korean Chem. Eng. Res.(HWAHAK KONGHAK), 51,
$1-6(2013)$.

17. Alexander, W. J. and Mitchell, R. L., "Rapid Measurement of Cellulose Viscosity by Nitration Methods,' Anal. Chem., 21, 14971500(1949).

18. Lee, P., Lee, J., Lee, H., Yeo, J., Hong, S., Nam, K. H., Lee, D., Lee, S. S. and Ko, S. H., "Highly Stretchable and Highly Conductive Metal Electrode by Very Long Metal Nanowire Percolation Network," Adv. Mater., 24, 3326-3332(2012). 